\title{
GRADUATE ATTRIBUTES: HOW SOME UNIVERSITY STUDENTS EXPERIENCE AND LEARN THEM
}

\author{
E. Bitzer* \\ email: emb2@sun.ac.za / https://orcid.org/0000-0003-4081-8053
}

\author{
M. Withering* \\ e-mail: mwithering@gmail.com \\ *Department of Curriculum Studies \\ Stellenbosch University \\ Stellenbosch, South Africa
}

\section{ABSTRACT}

The voices of university students are often absent from academic discourses on the learning of graduate attributes (GAs). Such attributes are mostly constructed and conceptualised from the viewpoint of academics, institutions, education authorities and industry. However, as students within democratic contexts are increasingly challenged to assume greater responsibility for their own growth and development, it seems imperative that they participate in discussions related to the acquiring of graduate attributes. This article reports on how students at one South African university understand and relate to graduate attributes. Data were generated from a group of students at the University of the Western Cape through focus group interviews and photo elicitation. The results indicate that students who understand what graduate attributes are and how they can acquire these attributes might enhance such students' further growth and their employability.

Keywords: graduate attributes, university students, employability, University of the Western Cape

\section{INTRODUCTION}

There are several reasons why student graduate attributes have become increasingly important within the South African context. Rapid societal, educational and technological changes exert pressure for students to succeed and for higher education to prove its worth (McCabe 2010). Public universities are thus increasingly concerned with graduating students with the skills and qualities that would enable them to be active citizens who contribute to civil society and economic activities (Barrie 2006). Similarly, pressures from governments and the private sector have increased to provide competent professionals and employable graduates (Brits 2018, 39). What is somewhat disturbing, however, is that the discourse on graduate attributes is dominated by university staff and other stakeholders, including national governments and industry (Legget 
et al. 2004, 295). The student voice in the graduate attribute debate is conspicuously subdued. This article reports an inquiry into students' perceptions and constructions of graduate attributes within one South African university. Obviously, studies related to perceptions and meaning construction are complex, given the different influences on and understandings of individuals. In addition, there is a general paucity of research on students' perceptions and understandings of graduate attributes internationally, which makes the topic even more challenging (Collier, Jobbins and Taylor 2009; Su 2014; Leggett et al. 2004; Jansen and Suhre 2015).

Although students recognise that "soft" skills such as communication and critical thinking, which are often outlined within graduate attribute charters, are important, they often do not understand these as "graduate attributes". This highlights a mismatch in the way GAs are articulated and how students understand them.

\section{THEORETICAL CONSIDERATIONS}

\section{What are graduate attributes?}

Given the rapid pace of change in an age of super complexity, there is increased pressure for students to succeed and for higher education to prove its worth (McCabe 2010). Increasingly, universities worldwide have sought to unravel the notion and the type of education they offer through the drafting of generic attributes charters (Bosanquet, Winchester-Seeto and Rowe 2010). These charters outline what higher education institutions expect their students to have acquired upon the completion of degree programmes. This view includes that all students would develop certain attributes which transcend disciplinary knowledge as a result of the institutional learning experience (Barrie 2012; Collier et al. 2009). Universities also emphasise these attributes to increase students' employability prospects (Treleaven and Voola 2008).

The conversations around the nature of graduate attributes have become "more, ... finegrained over time" (Green, Hammer and Star 2009, 5), but in spite of better refinement, there appeared to be a lack of conceptual clarity about the term (Green at al. 2009). This thought is echoed by Kew $(2014,7)$, who states that as there is little agreement on how to define the term as it leaves little "... consensus on which graduate attributes higher education institutions should go about instilling in their students". Various authors (Barrie 2012; Bester 2014, 66-67; Leggett et al. 2004; Mashiyi 2015; Treleaven and Voola 2008; Oliver, Herrington and McLoughlin 2000) have provided iterations of the term, ranging between transferable skills, generic skills, generic capabilities, employability skills and others.

Within the South African context, graduate attributes have attained widespread applications (Kew 2014, 7), but looking into how and when such attributes are acquired remains 
a complex undertaking. The variety of meanings and contexts contributes towards the confusion around what exactly institutions can expect of students at different stages of their education and particularly towards graduation (Kew 2014, 7). While there is continued debate around use of the correct terminology, the importance of graduate attributes as an essential outcome of a university education seems beyond doubt (Bester 2014, 84; Barrie 2012, 80).

One comprehensive but useful definition of graduate attributes was provided by Bowden et al. (2000, np):

"Graduate attributes are the qualities, skills and understandings a university community agrees its students should develop during their time with the institution. These attributes include, but go beyond, the disciplinary expertise or technical knowledge that has traditionally formed the core of most university courses. They are qualities that also prepare graduates as agents of social good in an unknown future."

Given this definition, one might say that graduate attributes are those qualities a higher education institution would want their graduates to exit with but which might not necessarily be embedded within the formal university curriculum. These qualities can be different for each student, as they develop in unique ways, given their different backgrounds as well as their institutional and personal learning experiences. Also, public higher education institutions are increasingly concerned with graduating students who have acquired skills, qualities and attributes that would enable them to be active citizens who can contribute to economic and civil society (Barrie 2006).

\section{International views on graduate attributes}

The notion of graduate attributes started predominantly in Australia, the United Kingdom, Europe and the United States of America (USA) through examining generic competencies and skills (Bester 2014, 66-67). Many of the discussions around graduate attributes began in the early 1990s as higher education institutions increasingly started working towards developing core workplace competencies. Thereby the need for employability skills, as identified by governments, civil society and industry were better articulated. In Australia, for instance, the view was held that the development of key competencies was "... the most direct and beneficial employment solution for the future" (Bester 2014, 69). The majority of Australian universities thus developed graduate attribute charters - now firmly entrenched in their higher education system (Bester 2014, 74-75). Rigby $(2009,3)$ has indicated that these charters are often based on “... a broad conceptualisation of generic skills in Australian universities, ... [which] encompasses anything from skill components to attitudes, values, dispositions, capabilities, and competencies". The broad uptake of the learning of graduate attributes in Australia may thus 
be largely ascribed to pressures from government and employers.

In the BRIC (Brazil, Russia, India, China) context higher education has been identified as playing an important role in societal transformation. Schwartzman, Pinheiro and Pillay (2015, 1-2) has indicated, for instance, that student attributes in these countries are important, “... not only in terms of human capital and access to the resources of modern science and technology, but also by creating channels for social mobility and fostering the values of scholarship, intellectual freedom, and individual choice".

The Indian higher education system is ranked as among the three largest in the world (Timm 2013, 161; Joshi and Ahir 2013, 43). Despite this, there seems to be a lack of attention to graduate attribute development. This may be in part due to the diversity and complexity of the Indian higher education system which, as Joshi $(2016,237)$ contends, has to grapple with “... regulations, access, financing, equity, efficiency and quality”. Within China, as in many other countries, the impact of massification is of concern due to its potential impact on the quality of higher education. $\mathrm{Li}$ (2015) contends that in order to promote graduate quality amidst massification it is necessary to develop and promote a common set of graduate attributes.

\section{Graduate attributes in African higher education}

Higher education in Africa is influenced by a variety of factors. These range from its colonial past to the brain drain of graduates and staff and to politics, poverty, global inequality and the low output and quality of research across the continent, to name a few. By focusing on graduate attributes, many higher education institutions across the continent have begun to address these kinds of difficulties. For instance, Kroeze, Ponelis, Venter, Pretorius and Prinsloo (2012) argue that there is an increased importance placed on graduate attributes, especially within SubSaharan Africa. Discussions increasingly revolve around what attributes are needed for those graduates from Sub-Saharan Africa which might be unique and relevant to the region.

\section{Graduate attributes in South African higher education}

The university system in South Africa has a long history, which dates back to the 1800 s. Prior to 1994, the main focus of higher education policy was directed at advancing institutions for white citizens. There was segregation permeating the sector, which was separated not only by race, but also by geography and language, with the majority of urban institutions being reserved for white students.

The institutions created for people of colour had a purpose of ensuring continued separation and education of black and coloured people in homelands and rural areas. There was no equity prior to 1994, neither in terms of funding, study options, capacity nor students 
enrolled in certain programmes (Hay and Monnapula-Mapesela 2009). This led to an underrepresentation of black people in areas such as science, technology and engineering as many people of colour did not have access to such study programmes. As Hay and MonnapulaMapesela $(2009,12)$ have pointed out: “... the system was characterised by fragmentation, inefficiency and ineffectiveness".

The end of apartheid facilitated a need for a change in the way higher education in South Africa was structured, functioned and populated (Carrim and Wangenge-Ouma 2012). This transformation was necessary to address the need for greater participation, responsiveness and cooperation. Apartheid had resulted in much fragmentation of access and opportunity for students along the lines of race, gender, geography and the "... mismatch between higher education output and the needs of a modernising economy" (Carrim and Wangenge-Ouma 2012, 8).

However, South African higher education institutions face a challenging and critical role as they continue to navigate the legacy of its past through delivering graduates who are critical and engaged citizens (Bawa 2014; Clowes 2013; Costandius and Bitzer 2017). The sector has been mandated to develop "... critical, active participants in our democracy ..." through the development of high-level graduates (Bawa 2014, v). Despite this focus on developing a graduate skills base, Carrim and Wangenge-Ouma (2012, 21-22) contend that graduate skills development has not been keeping pace to meet demands. Increasingly, higher education is called upon to assist the South African economy to grow through the production of skilled graduates (Winberg et al. 2018, 234) and student graduate attributes have been articulated at different levels. For instance, the African Qualifications Authority (SAQA) has defined these attributes as "... those generic outcomes that inform all teaching and learning" (Kew 2014). However, both Kew $(2014,6)$ and Mashiyi $(2015)$ contend that there is a serious paucity of research on graduate attributes in the South African context. Nell and Bosman (2017) also highlight that often, institutional policies on GAs are implemented without a careful consideration of the contextual basis within which it is positioned.

The paucity of research into graduate attributes at the institutional level can be explained by a number of factors. These include academics that are under immense work pressure, the under-resourcing of the higher education system and an increased focus on getting students out of the system as quickly as possible. These factors, amongst others, have resulted in little time available to focus on the development of student attributes and inquiry into this field.

\section{Students' views on graduate attributes}

Kavanagh and Drennan $(2008,295)$ referred to the fact that “... students are a key stakeholder 
group when it comes to examining views about developing skills and attributes to equip them for a career ..." In practice, however, not much thought is being given to the student voice. Donleavy $(2012,350)$ highlights that “... graduate attributes are often assessed for, rather than with, students." A key point made here is that graduate attribute development can fail if students are "... not actively engaged as partners in the assessment process" (Donleavy 2012, 350). Students are apparently often ignored in discussions around graduate attributes, with a "topdown" approach adopted (Su 2014). This view is supported by Barrie (2006) and Leggett et al. (2004) who suggest more research on students' perceptions and their own construction of graduate attributes.

Crebert et al. (2004) and Collier et al. (2009) both make an important point, namely that an understanding of student perceptions of the importance of graduate attributes can inform the development of effective, inclusive learning activities that meet the needs of students from all backgrounds. At the same time, however, Oliver et al. (2000) have pointed out that defining the full range of generic and transferable skills that might be useful for university students is a difficult and exhaustive process.

\section{AN INSTITUTIONAL CASE}

The present study focused on students at the University of the Western Cape (UWC) a traditional contact university. The University can currently be classified as a comprehensive, medium-sized university, given an enrolment of between 20000 and 30000 students. Considering the diversity profile of the students at UWC, it was possible to identify general student categories under rubrics such as gender, age, race, sexual orientation, religion and social class. A large proportion of the student body are "first-generation" students, meaning they are the first members of their family to attend or graduate from a higher education institution. Firstgeneration students generally have some shared experiences based on similar diversity traits.

Students are also mainly from poorer working class homes, and with low levels of throughput and completion, despite increased access. Such students often also present with limited social capital attributed to a number of factors such as support, finance, residence and health (see, for instance, Lewin and Mawoyo 2014, 41; Haldenwang 2015, 2).

Ethical clearance for the study was obtained from the university where the study was supervised and institutional permission to conduct the study at the particular site was granted by UWC.

\section{Research design}

The study generated data via focus group interviews and photo elicitation methods. The 
institutional case included a group of purposively selected students at the UWC. Student participants were those registered as undergraduate UWC students and selected from the programme offerings of the Leadership and Social Responsibility (LSR) office. The sample was not intended to be an institutionally representative group, but rather to understand how some UWC students experience the learning of GAs. The LSR office was established in 2008 as a directive of the division for Student Development and Support under the Centre for Student Support Services (CSSS). As part of the UWC Institutional Operating Plan (IOP) 2010-2014, the development of students was identified as a key focus area.

The students who participated in this study were conveniently drawn from the cohort of Emerging Leaders (ELP) ${ }^{1}$, Advanced Leaders (ALP) ${ }^{2}$ and InitiAct Leaders (ILP) ${ }^{3}$ students in 2016. Table 1 overviews the socio-demographic characteristics of participants.

Table 1: Socio-demographic details of selected student participants

\begin{tabular}{|l|l|}
\hline Gender & Female: 4; Male: 6 \\
\hline Year of study & $3 \times 3^{\text {rd }}$ year; $7 \times 2^{\text {nd }}$ year \\
\hline Faculty & Economic Sciences: 3 \\
& Community and Health Sciences: 3 \\
& Law: 2 \\
& Natural Sciences: 1 \\
& Arts: 1 \\
\hline Age & Age 20: 1; Age 21: 5; Age 22: 3; Age 29: 1 \\
\hline LSR programme & ALP: 7; ILP: 2; ELP: 1 (see footnotes) \\
\hline Race & Coloured: 3; Black: 6; Not identified: 1 \\
\hline Nationality & South African: 9; Zimbabwean: 1 \\
\hline
\end{tabular}

A general email call was issued requesting the participation of students in the study. All students had a common shared experience of being enrolled at UWC, being involved in co-curricular programmes linked to graduate attribute development as offered through the office of Leadership and Social Responsibility (LSR) and in completing their undergraduate studies. The research therefore employed non-probability convenience sampling to select participants who were willing to participate, who were accessible and were convenient to involve (Bryman 2012).

Responses were received from 18 students who were initially interested in participating. Of initial eighteen only 10 eventually arrived at the initial interview. Of the ten, seven (7) students agreed to participate in the photo elicitation exercise. Four (4) out of the seven students eventually returned photos and continued with the photo elicitation aspect of the study. Overall, the following exclusion criteria applied:

- Students who were not registered at UWC 
- Students not involved in the programme offerings within the LSR office

- Students in postgraduate study; and

- Students from LSR, but involved prior to 2016.

\section{Focus groups and photo elicitation}

Students across the institution were invited to participate in focus group interviews in 2016. A total of ten information rich cases were finally selected for the first focus group interview. This afforded an initial opportunity to understand how students thought about and experienced the learning of graduate attributes.

The questions that were included in the initial focus group interview included the following: (1) Have you heard about graduate attributes before? What does graduate attributes mean to you? (2) Does UWC have any graduate attributes policy that you know of? (3) Do you think that there is any value in graduate attributes? E.g. that it might help with your employment, understanding of self, professional development? (4) Do you think UWC does enough to promote graduate attributes in the curricular and co-curricular space? (5) How does your faculty or degree programme promote graduate attributes? (6) Is there anything else that you would like to add and which relates to GAs?

A follow-up focus group interview was conducted later in 2016 to expand on the issues highlighted in the first round and eventually four students agreed to participate in the elicitation of photographs (see Schulze 2007, 541) to depict their understanding and experience of graduate attributes. To eliciting meaning from photographs, individual interviews were also conducted with the final four participating students.

\section{Photo elicitation}

Photo elicitation is based on the idea of inserting a photograph into a research interview (Harper 2002). This allows for active engagement in the research process by participants as photographs taken by them evoke meaning beyond the obvious and "... extend personal narratives that illuminate lives and experiences" (Clark-Ibáñez 2004, 1508). The images themselves do not necessarily have an intrinsic meaning, but participants assign different meanings to them and then have to explain these in photo elicitation interviews (Schulze 2007, 540).

Student participants were asked to take photographs of instances or objects in and around the UWC campus that they considered linked to graduate attributes and then to provide a short, written description or narrative of each photograph. Images captured by students in their photographs included 
- $\quad$ signs around campus that restrict, rather than promote, the learning of graduate attributes

- technological objects such as cell phones and computers, closely associated with learning communication and technological skills

- student diaries, depicting the need to learn how to plan, manage and organise, and

- student groups and friends, which relate to learning about cultures, diversity and building relationships.

The interviews that were conducted with the four students included, but were not confined to, the following open-ended questions:

(1) The students were firstly asked to explain what each of their photographs elicited and meant to them in terms of explaining their experience of GAs at UWC.

(2) Then, in more detail: (a) "How does this photo/s represent your understanding of learning graduate attributes at UWC?" (b) "Why did you take this particular photo?" (c) "What does your photo communicate in essence?"

(3) Anything else you would like to elaborate on in terms of your experience of GA learning at UWC?

\section{DATA ANALYSIS}

The narratives from the interviews were recorded, transcribed and reviewed for themes that were coded in the same way as the photographs and accompanying descriptions and narratives. These codes are most often a word or short phrase that "... symbolically assigns a summative, salient, essence-capturing and/or evocative attribute for a portion of language based or visual data" (Saldaña 2009, 3; also see Koen 2011).

\section{FINDINGS}

\section{Awareness of graduate attributes}

A first finding from the study was a varied level of understanding amongst the small cohort of participants of the learning of graduate attributes. From the initial group interviews, for instance, at least forty per cent of the student participants had not heard about the term "graduate attributes" prior to the study. The rest all had different understandings of the term. This mixed awareness was not limited to specific faculties, year of study or gender. 
This mixed awareness could be a result of inconsistency around how graduate attributes are articulated to students via the curriculum, co-curricular and institutional structures and policy. For instance, students highlighted this inconsistency with some sharing of how the learning of graduate attributes was facilitated through extended learning programmes and in cocurricular programmes, but seldom in regular degree curricula.

\section{Awareness of the UWC attributes charter}

What further emerged was that despite biographical differences among students (e.g. faculty, gender, age), there were similarities in what they indicated as being important graduate attributes. These attributes matched the key attributes outlined in the UWC Attributes Charter (Teaching and Learning Unit UWC 2009) in several respects. One might thus assume that although the term "graduate attributes" might be unfamiliar to students, there is a clear recognition of the importance of attributes such as, for instance, employability.

Furthermore, student participants in the study were not aware of whether UWC has a graduate attributes charter and the contents of the attributes outlines in such a charter. What this implies is that the current institutional approach to sharing graduate attributes with students seems inconsistent. This was highlighted by participant "Chiddy"4 who remembered: "We did it in first year. I don't recall ... I know there are five of them, I just don't recall them specifically". Other participants corroborated this statement with "Sisonke" sharing, "I've never heard about them in class; I just knew that 'okay maybe it's something that you should have', but then I was just like 'maybe I'm wrong, let me just keep quiet because I don't know where this is going'." This raises the point of who should be responsible for graduate attribute development, which will be discussed later.

Student participant "Gio" provided an alternate account of his experience, which also relates to Barrie's (2007) theoretical framework. He specifically touched on an aspect within both the remedial and associated conception and shared the following: “... [T]here was one course in my first year ... they made it explicit ... so it was just those specific people in the academic development department, in foundation year because the mainstream doesn't get, ... what the mainstream gets ..." It seems that in many cases graduate attributes were made explicit in the first year of study but then not touched on again. Many institutions do focus on the first year experience (UWC: First years First; Stellenbosch University: First-year Academy (FYA); University of Free State: Gateway First-year College) but subsequent years do not seem to receive the same level of focused support.

Another point raised by "Gio" is that exposure to graduate attributes came through the cocurricular programme and was offered to foundation-level students. For instance, UWC 
provides opportunities for students who often would not have access to university due to their grade 12 results. The foundation programme offers support in the form of intensive assistance in helping students to gain skills for success at university, coupled with a lighter course load (University of the Western Cape 2013). This connects again to Barrie's $(2007,445)$ idea that graduate attributes are often promoted in parallel modules or workshops for students rather than being embedded in programme curricula.

\section{Students' self-interest}

What further emerged from the study is that student participants' understandings of how attributes develop appear to be vastly different. This aspect speaks again to the perceptions students hold and what is important to one person might not be important to another. Student "Penny" stated this point as follows: “... what I may perceive as a graduate attribute not everyone is going to so, yeah, perception of a graduate attributes differs per person. It is an individual process". This seems a key point, as it indicates how graduate attribute perceptions are often interpreted and understood at the individual level. Understanding students' perceptions thus moves us away from seeing students as passive "recipients" of graduate attributes, towards seeing them as active participants in the construction of the meaning of such attributes. This position corresponds to Barrie's (2007) view that attributes being developed through the way students participate in the experiences of university life.

Some students outlined the importance of various co-curricular activities in acquiring graduate attributes. Student "Gio", for instance, reiterated: "I think becoming a part of an organization exposes you to various different graduate attributes ... so I think the university provides many opportunities outside of class for students to develop these graduate attributes before they graduate". Others indicated the importance of their interest in their own personal development and how they promoted that. This brings to the fore the issue of who takes the responsibility for the development of graduate attributes. Should the development of graduate attributes be the responsibility of the institution, the academics or the students themselves, or is this a shared responsibility among all three parties?

From photograph elicitation a number of students indicated how they engage with graduate attributes at the institution through participation in co-curricular programmes, working in teams and communicating within diverse groups of students. This position connects with the UWC Graduate Attribute Charter (Teaching and Learning Unit UWC 2009), in particular referring to graduates becoming both autonomous and collaborative - with abilities to work both within teams and independently. Student "Mo", for instance, highlighted the importance of communication skills and developing students as skilled communicators (UWC Charter of 
Graduate attributes 2009).

One view that emerged was that everything was about students. Student "Bushido" was of the opinion that: “...there's no development unless you want to", while "Penny" argued: "I think it falls back on what you perceive as what is needed for yourself, not only for a workplace or academically ... it comes back to you". "Penny" also made the point that perhaps values and beliefs of the individual play a role in attribute development. These differences in student perceptions might be due to differences in self-evaluation and, consequently, it seems necessary to engage students in graduate attribute development in order to become more meaningful and real to them.

The study's empirical results have shown the importance of recognising students as active agents in the understanding and development of their own graduate attributes. The acquiring or development of such attributes should thus not be a process "done to" students, but rather "with the involvement" of students as individual priorities and self-interest play an important part in how students seem to take up the challenge of developing attributes for themselves - often outside of the formal university curriculum.

\section{Importance of staff in the attainment of graduate attributes}

A key finding which emerged from the study is the value placed on teaching staff to promote the learning of graduate attributes. Student "Chiddy" provided a good summary of the problem: "So, that link is not there; I think that's why most students do not know about any of this and that's why it's always on paper because the university is the paper and the lecturers are the face of the university." What this highlights is the importance of lecturing staff in the development of graduate attributes and the necessity of having staff embracing the concept. This is often problematic, as pointed out by Barrie $(2012,79)$, showing that academics tend to hold "... qualitatively different conceptions of the phenomenon of graduate attributes" - often resulting in differences about the importance or relevance of graduate attribute development and how it is to be taught and learnt.

A British Council $(2015,1)$ report on South Africa confirms the importance of programme curricula in graduate attribute development: “... the quality of teaching, and teaching methods significantly influences intellectual and personal development and the formation of critical knowledge and skills for working in a diverse society." Student views in our study corroborated with this point. Student "Bushido", for instance, said: “... the university has all these great things on paper, but when it comes to implementing it, we don't even get that enthusiasm from lecturers themselves. So how do you develop as a critical thinker when your lecturer doesn't even seem interested in lecturing the work itself?" Student "Mo", however, offered an 
alternative: "... in our faculty, the lecturers build close relations with students, so they encourage us to come to them ... not just in class, but outside or in their office, I can easily go consult with them ...".

What seems somewhat disturbing, and clearly reflected in literature, is the little consistency amongst lecturing and support staff as to how graduate attributes should be developed. This issue has been raised by authors such as Barrie (2006) and Green et al. (2009) who have pointed out that differences in lecturers' incoherent definitions of graduate attributes lead to "patchy implementation" (Barrie 2006, 6) - often the result of individual (mis)understanding around these attributes. In our study some participants revealed that their exposure to graduate attributes that came as part of course outlines or module descriptors were very limited. Student Penny, for instance, emphasised this point: “... I just think there isn't much exposure to the learning of graduate attributes at the university". However, graduate attributes are mentioned in course outlines and as part of module descriptors, they are not highlighted and clarified during the course. This, in turn, may account for students not being familiar with them. This was also reiterated by student "Amazon" who stated: “... for each of my modules in the course outline, there would be graduate attributes but ... I'm not sure if they are specific to the module". This could be related to what Winberg et al. $(2018,235)$ have highlighted as university staff lacking understanding of graduate attributes and how they are promoted and learnt, thus demonstrating a general sense of apathy or resistance. What this means is that the institutional commitment to attribute development cannot be guaranteed as the "face of the institution" (Oliver 2013, 453). Student "Chiddy" was able to articulate her view as follows:

“... lecturers are not intertwined per se because they are similar to us; they are here to do a work and we are here to learn, and then the university has its own attributes and things but then they don't tell the lecturers and then they don't inform the lecturers to incorporate it into their teaching, because I think if they did that the learners - because the learners have the interaction with the university via the lecturers, not directly. So that link is not there; I think that's why most students do not know about any of this and that's why it's always on paper because the university is the paper and the lecturers are the face of the university, essentially because that's the only people we see and interact with so I think that's where ... uhm ... the problem is, that there's no link."

The inconsistency amongst staff around graduate attributes at universities in general is not a new phenomenon. This is despite a push to the contrary from governments, employers and institutions - a factor also highlighted by Barrie (2012) and Bester (2014). Often the reason for graduate attributes not being promoted is that lecturing staff would have fundamentally different views of such attributes. The interest of staff in the development of student attributes and skills is also often an indication of whether attributes would be given any additional time or emphasis within the curriculum. 
Lecturing staff may place emphasis solely on discipline content, which might be a result of the differences between disciplines, some of which might not lend themselves well to incorporate or promote graduate attributes into the core curriculum. Additionally, the level of interest of lecturers in the development of graduate attributes, as well as the limitations provided by practical issues such as timetables and modular credits, may have a negative impact on the foregrounding of such attributes. However, only the views of students are reported in the present article. The views of university staff, which falls outside the scope of the present article, will be a further interesting issue to explore in comparison to the views and experiences of students.

\section{IMPLICATIONS OF THE STUDY}

The present study points to a number of important implications at the level of theory, practice and future research.

\section{Theoretical implications}

Firstly, there needs to be a re-engagement with graduate attributes at a theoretical level throughout the university. This does not only pertain to UWC as a case in time, but may be true for most universities in South Africa (see, for instance, Bawa 2014; Brits 2018; Winberg et al. 2018). As has been pointed out in our study, students are often uninvolved in the process of discussing and debating the underpinning departure points of this domain of inquiry. Staff at all levels, but especially the lecturing staff, need to reach some common understanding or conceptualisation of graduate attributes and how it could be developed within the institutional context.

Secondly, what could contribute to the graduate attribute debate is the setting of "minimum standards" to ensure that students are engaged in the introduction and promotion of the concept of graduate attributes. To have graduate attributes confined to course outlines and a few co-curricular activities seem to be grossly ineffective, as also clearly shown by previous studies (see Griesel and Parker 2008; Collier et al. 2009; Barrie 2012; British Council 2015). What might be needed is scholarly debate around graduate attributes and some institutional recommitment to their promotion - not as an abstraction or once-off discussion, but as a continuous process of checking and rechecking to ensure their relevance to students, staff, society and employers.

\section{Practical implications}

The study findings have clearly indicated multiple ways in which graduate attributes could be developed. This might necessitate UWC, and possibly other public universities too, to clarify 
how such development might take place. The aim being to have a greater level of consistency of graduate attribute development among programmes, faculties and year levels. As Barrie (2006; 2007) has pointed out, there needs to be a shift in how teaching is conducted in higher education from merely delivering information and skills to rather, as Bester $(2014,4)$ outlines, the creation of "... curricula that support a holistic, emancipatory, reflective, life-wide and lifelong learning process". This implies some review of how programmes are offered and learning is facilitated - and in particular, how graduate attributes are situated and learnt within the institutional curriculum.

What the current study has also shown is the need for institutional communication between formal curricula and the co-curricular project to prevent disjuncture and ensure that the development of graduate attributes is not relegated as the responsibility of the one or the other. Embedding attributes within all areas of learning within the institution is important as this offers students the opportunity to develop attributes in ways that best suit their learning styles, approaches and what they regard as important for their future careers and learning.

\section{Implications for future research}

The present study has highlighted that further research might be needed at UWC (and probably also at other public South African universities) into students' perceptions of their learning of graduate attributes. More research and analysis seem to be needed to show how students can be more engaged and involved in the understanding, learning and value of graduate attributes. Such research could be strengthened by inquiring into graduate attributes with a focus on the link between graduate attributes, employability and societal contributions (also see previous studies, including Creber et al. 2004; Griesel and Parker 2009; Jansen and Suhre 2015; Li 2015), which seems an important issue for higher education, future employers of graduates and society at large in South Africa.

A final suggestion for a future research agenda item involves further studies around staff at all levels of the university to determine their level of engagement with the learning and development of graduate attributes. This issue was also previously highlighted by authors such as Koen (2011), Mashiyi (2015) and Nell and Bosman (2017) and underscores the need to investigate how, for instance, new staff could be best orientated towards promoting graduate attributes with their students. Such research may also promote the development of learning programmes and courses, which would afford lecturers more time and a firmer platform to make connections between course material and the learning of graduate attributes.

As the promotion and development of graduate attributes are relatively recent within the South African context, and given the focus of this study on one university, it might necessary 
for further research to continue this important topic. This is especially true as we move towards a more collaborative and mutually beneficial approach to higher education to ensure that graduate attributes are characterised by relevance and meaningful university learning outcomes.

\section{CONCLUDING REMARKS}

The nature of higher education and the demands of society necessitate that students be equipped beyond mere disciplinary knowledge. Discussions around graduate attributes cannot be dismissed, as to do so will do a disservice to students who need to be prepared to face an uncertain future, which awaits them after completing their formal degrees. Academic and other staff will probably need to be fully and continually briefed on the possibilities and practices of graduate attribute learning.

Students should be engaged in discussions around graduate attributes as such engagement has a direct impact on them and how they emerge from universities as lifelong learners. The integral role of staff in the dissemination of information around graduate attributes is critical and a process of educating staff around a commonly agreed definition of graduate attributes is necessary. Finally, it can be emphasised that the development of graduate attributes is not the sole responsibility of any university but might be much better served by the combined responsibility of individual students, their curricular and co-curricular programmes and society at large.

\section{NOTES}

1. The Emerging Leaders Programme is a co-curricular programme designed for participants who want to develop their leadership skills. It is designed for participants who want to grow, who want to be challenged and who see the need for responsive and responsible citizenship.

2. The Advanced Leaders Programme is an extension of ELP and ILP. Participants are exposed to leadership and challenged to deepen their knowledge by analysing issues within the framework of the university, their communities and the global environment.

3. The InitiAct Leaders programme is offered over five sessions on selected Saturdays throughout the year. The sessions cover four pillars of leadership development: General Leadership, SelfDevelopment, Building Sustainable Support Networks and Practical Project Skills.

4. All names used are pseudonyms

\section{REFERENCES}

Barrie, S. C. 2006. Understanding what we mean by the generic attributes of graduates. Higher Education 51(2): 215-241.

Barrie, S. C. 2007. A conceptual framework for the teaching and learning of generic graduate attributes. Studies in Higher Education 32(4): 439-458.

Barrie, S. C. 2012. A research-based approach to generic graduate attributes policy. Higher Education Research \& Development 31(1): 79-92.

Bawa, A. 2014. Foreword in Perspectives on Student Affairs in South Africa, ed. M. Speckman and M. 
Mandew, i-v. African Minds. South Africa.

Bester, M. 2014. Academics' conceptions and orientations of graduate attributes in applied design programmes at a university of technology. Stellenbosch: Stellenbosch University. Unpublished Master's thesis.

Bosanquet, A., T. Winchester-Seeto and A. Rowe. 2010. Changing perceptions underpinning graduate attributes: A pilot study. Research and Development in Higher Education 33: 105-117. Special edition on "Reshaping Higher Education".

Bowden, J., G. Hart, B. King, K. Trigwell and O. Watts. 2000. Generic capabilities of ATN university graduates. Canberra: Australian Government Department of Education, Training and Youth Affairs. http://pandora.nla.gov.au/pan/34352/20030513-0000/www.clt.uts.edu.au/ATN.grad.cap. project.index.html (Accessed 31 January 2017).

British Council: International Higher Education. 2015. Student perceptions of employability and inclusive development: South Africa. https://www.britishcouncil.org/sites/default/files/2.5_ student-perceptions-of-employability-inclusivity.pdf (Accessed 27 September 2018).

Brits, H. J. 2018. Assessing employer satisfaction: An attempt to enhance graduate employability at an institution of higher learning. South African Journal of Higher Education 32(5): 39-53.

Bryman, A. 2012. Social research methods. Oxford: Oxford University Press.

Carrim, N. and G. Wangenge-Ouma. (Ed.). 2012. Higher Education in South Africa. Cape Town: British Council of South Africa.

Clark-Ibáñez, M. 2004. Framing the social world with photo-elicitation interviews. American Behavioural Scientist 47(12): 1507-1527.

Clowes, L. 2013. Teacher as learner: A personal reflection on a short course for South African university educators. Teaching in Higher Education 18(7): 709-720.

Collier, M., S. Jobbins and R. Taylor. 2009. Student perceptions of graduate attributes in the Bachelor of Animal and Veterinary Bioscience. Unpublished paper delivered at the Australian Conference on Science and Mathematics Education (formerly UniServe Science Conference).

Costandius E. and E. M. Bitzer. 2017. Engaging higher education curricula. A critical citizenship education perspective. Stellenbosch: African Sun Media.

Crebert, G., M. Bates, B. Bell, C.-J. Patrick and V. Cragnolini. 2004. Developing generic skills at university, during work placement and in employment: Graduates perceptions. Higher Education Research and Development 23(2): 147-165.

Donleavy, G. 2012. Proclaimed graduate attributes of Australian universities: Patterns, problems and prospects. Quality Assurance in Education 20(4): 341-356.

Green, W., S. Hammer and C. Star. 2009. Facing up to the challenge: Why is it so hard to develop graduate attributes? Higher Education Research and Development 28(1): 17-29.

Griesel, H. and B. Parker. 2008. Graduate attributes: A baseline study on South African graduates from the perspective of employers. Pretoria: Higher Education South Africa (HESA) \& South African Qualifications Authority (SAQA).

Haldenwang, B. (comp). 2015. A socio-demographic profile of South Africa's youth. Strategy Insights Social 20(1): 1-7.

Harper, D. 2002. Talking about pictures: A case for photo elicitation. Visual Studies 17(1): 13-26.

Hay, D. and M. Monnapula-Mapesela. 2009. South African higher education before and after 1994: A policy analysis perspective. In Higher education in South Africa: A scholarly look behind the scenes, ed. E. Bitzer, 3-20. Stellenbosch: African Sun Media.

Jansen, E. P. W. A. and C. J. M. Suhre. 2015. Factors influencing students' perceptions of graduate attribute acquisition in multidisciplinary honours track in a Dutch university. Higher Education Research and Development 34(6): 1-14.

Joshi, K. M. 2016. Governance, growth and equity: Reflections from Indian Higher Education. Center for the Studies of Higher Education. http://www.cshe.nagoya-u.ac.jp/publications/journal/no16/ 
12.pdf. (Accessed 19 July 2018).

Joshi, K. M. and K. V. Ahir. 2013. Indian higher education: Some reflections. Intellectual Economics 7(1): 42-53.

Kavanagh, M. and L. Drennan. 2008. What skills and attributes does an accounting graduate need? Evidence from student perceptions and employer expectations. Accounting and Finance 48(2): 279-300.

Kew, B. 2014. A study of the relationship between students' participation in the commerce education development unit and their graduate attributes. Cape Town: University of Cape Town. Unpublished Master's dissertation.

Koen, M. 2011. Exploring assessment for learning in one higher education classroom. Stellenbosch: Stellenbosch University. Unpublished Master's thesis.

Kroeze, J. H., S. R. Ponelis, I. M. Venter, P. D. Pretorius and P. Prinsloo. 2012. Aligning African computing disciplines' graduate attributes with international standards. International Multiconference on Society, Cybernetics and Informatics. July.

Leggett, M., A. Kinnear, M. Boyce and I. Bennett. 2004. Student and staff perceptions of the importance of generic skills in science. Higher Education Research \& Development 23(3): 295-312.

Lewin, T. and M. Mawoyo. 2014. Student access and success: Issues and interventions in South African universities. Cape Town, Inyathelo: The South African Institute for Student Advancement.

Li, T. 2015. Required graduate attributes in Hong Kong and their relative importance. European Scientific Journal 11(34): 1857-7881.

Mashiyi, F. N. 2015. Embedding graduate attributes into the foundation programme: Reflections on process and product. South African Journal of Higher Education 29(1): 181-197.

McCabe, G. 2010. Graduate attributes and employability: Helping universities and students prepare for the changing landscape. Centre for Teaching, Learning and Assessment. The University of Edinburgh. http://www.ed.ac.uk/files/atoms/files/ga-helping_uni_and_students_prepare_-march 2010.pdf (Accessed 9 March 2017).

Nell, I. A. and J. P. Bosman. 2017. Integrating graduate attributes into a master of divinity programme at a South African university. South African Journal of Higher Education 31(1): 175-190

Oliver, B. 2013. Graduate attributes as a focus for institution-wide curriculum renewal: Innovations and challenges. Higher Education Research and Development 32(3): 450-463.

Oliver, R., J. Herrington and C. McLoughlin. 2000. Exploring the development of students' generic skills development in higher education using a web-based learning environment. In Proceedings of World Conference on Educational Multimedia, Hypermedia and Telecommunications, ed. J. Bourdeau and R. Heller, 848-854. Chesapeake: VA: AACE.

Rigby, B. 2009. Review of graduate skills: Critical thinking, teamwork, ethical practice and sustainability. Australian Learning and Teaching Council. http://www.graduateskills.edu.au/ wpcontent/uploads/2010/08/GraduateSkills_LiteratureReview.pdf (Accessed 9 March 2017).

Saldaña, J. 2009. The coding manual for qualitative researchers. London: Sage Publications Inc.

Schulze, S. 2007. The usefulness of reflexive photography for qualitative research: A case study in higher education. South African Journal of Higher Education 21(5): 536-553.

Schwartzman, S., R. Pinheiro and P. Pillay. 2015. The rise of the BRICS and higher education dynamics. In Higher education in the BRICS countries investigating the pact between higher education and society, ed. S. Schwartzman, P. Pillay and P. Pinheiro, 44: 1-10.

$\mathrm{Su}$, Y. 2014. Self-directed, genuine graduate attributes: The person-based approach. Higher Education Research and Development 33(6): 1208-1220.

Timm, A. 2013. What is it like to study for an undergraduate degree in India? Some potential implications for the transition into taught postgraduate programmes abroad. Transnational Higher Education in the Asian Context, 161-182. London: Palgrave Macmillan.

Teaching and Learning Unit UWC. 2009. UWC charter of graduates' attributes and strategic plan for 
teaching and learning. file:///C:/Users/user/Downloads/Final\%20Integrated\%20Graduate\%20 Attributes\%20and\%20TnL\%20Strat\%20Plan\%20Documen\%20(3).pdf (Accessed 12 December 2016).

Treleaven, L. and R. Voola. 2008. Integrating the development of graduate attributes through constructive alignment. Journal of Marketing Education 30(2): 160-173.

University of the Western Cape Graduate Attributes Charter. 2009. file://C:/Users/user/Downloads/ Graduate\%20Attributes\%20Charter\%20(1).pdf. (Accessed 23 February 2017).

University of the Western Cape. 2009. IOP 2010-2014 Goal 1-8 CSSS alignment slide 9 20/11/2009. PowerPoint Presentation.

University of the Western Cape. 2013. Prospectus: Admissions Requirements General Criteria for Admission to the University 2017. http://prospectus.uwc.ac.za/educate/admissions-requirements/ (Accessed 30 May 2018).

Winberg, C., A. Staak, M. Bester, S. Sabata, D. Scholtz, R. Sebolao, M. Monnapula-Mapesela, N. Ronald, M. Makua, J. Snyman and P. Machika. 2018. In search of graduate attributes: A survey of six flagship programmes. South African Journal of Higher Education 32(1): 233-251. 